Contents lists available at http://ejournal.uin-suska.ac.id

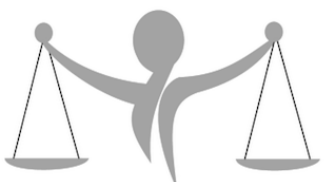

Al-Ittizaan: Jurnal Bimbingan Konseling Islam

ISSN: $2620-3820$

Journal homepage: http://ejournal.uin-suska.ac.id/index.php/alittizaan

\title{
Kondisi Psikologis Personil TNI-AD Menghadapi Pensiun
}

\author{
Mardhiah Rubani ${ }^{1}$ \\ ${ }^{1}$ Universita Islam Negeri Sultan Syarif Kaim
}

\begin{tabular}{l}
\hline Article Info \\
Article history: \\
Received September $12^{\text {th }}, 2018$ \\
Revised Oktober $20^{\text {th }}, 2018$ \\
Accepted Oktober $26^{\text {th }}, 2018$ \\
\hline
\end{tabular}

Keyword:

Personil TNI-AD,

Kondisi jiwa,

Pensiun

\begin{abstract}
Pembahasan ini bertolak dari pemikiran bahwa perlunya persiapan menghadapi pensiun. Melihat fenomena yang terjadi, ternyata ada sebagian pensiunan yang mengalami ketidaktenangan jiwa dalam menjalani masa pensiun. Ada mereka yang terkejut atas perubahan yang dialami setelah pensiun, yakni: biasanya mereka seorang pekerja yang sibuk, tekun dan optimis, kini hanya berdiam diri saja di rumah; biasanya mereka bersosialisasi dengan rekan-rekan kerjanya, kini hubungan tersebut terputus karena mereka tidak bekerja lagi sedangkan rekannya masih bekerja. Melihat gejalagejala diatas kemungkinan disebabkan oleh kondisi jiwa yang tidak siap menghadapi pensiun. Ini pertanda perlunya mempersiapkan diri dalam menyongsong masa pensiun. Kesiapan seseorang menghadapi pensiun diawali dengan kesiapan mereka menyongsong pensiun. Begitu pula kiranya yang terjadi pada diri personil TNIAD Makorem 031/Wirabima. Untuk menjawab permasalahan tersebut, penulis mengumpulkan data yang diperlukan melalui wawancara mendalam pada informan
\end{abstract}

(C) 2019 The Authors. Published by UIN Sultan Syarif Kasim Riau.

This is an open access article under the CC BY license

(https://creativecommons.org/licenses/by/4.0)

\section{Author:}

Mardhiah Rubani

${ }^{1}$ Universita Islam Negeri Sultan Syarif Kaim

Email:Mardhiah.Rubani@uin-suska.ac.id

\section{Pendahuluan}

Manusia tidak terlepas dari aktivitas bekerja. Ada orang yang bekerja untuk mencari uang, ada yang bekerja untuk mengisi waktu luang, ada pula yang bekerja untuk mencari identitas, dan alasan kebutuhan lainnya. Apapun alasan manusia bekerja, semuanya adalah untuk memenuhi kebutuhannya. Secara garis besar kebutuhan manusia dapat dibagi menjadi kebutuhan fisiologis, kebutuhan rasa aman, kebutuhan kasih 
sayang, kebutuhan harga diri, dan kebutuhan aktualisasi diri, hal ini diungkapkan oleh Maslow (Feist dan Feist, 2008).

Bila ditelusuri lebih jauh, suatu pekerjaan lebih berkaitan dengan kebutuhan psikologis seseorang dan bukan hanya berkaitan dengan kebutuhan materi semata. Secara materi, orang bisa memenuhi kebutuhan sandang pangan melalui bekerja. Namun kebutuhan akan kerja secara psikologis adalah dapat menimbulkan identitas diri, status dan fungsi sosial.

Bekerja merupakan bagian fundamental dari kehidupan bagi hampir semua orang dewasa, baik pria maupun wanita, yang memberikan kebahagiaan dan kepuasan. Suatu kenyataan bila seseorang yang mampu mendapatkan penghasilan itu menandakan bahwa dirinya adalah manusia produktif, manusia yang berguna dan tidak menjadi beban bagi orang lain. Orang yang bekerja pada hakikatnya akan tiba pada suatu masa di mana individu tersebut harus berhenti dari pekerjaannya.

Pada waktu memasuki masa setengah baya, mereka harus menyadari kenyataan, yakni bahwa masyarakat sedang menggeser mereka ke waktu pensiun. Bagi seorang yang pensiun, terdapat tiga sikap umum di dalam situasi barunya; ada yang gembira karena sekarang mempunyai waktu luang; ada yang merasakan bahwa pensiun merupakan sesuatu yang alami; dan ada yang merasakan takut karena merasa akan diasingkan lingkungannya.

Pensiun merupakan suatu keadaan di mana individu sudah tidak lagi bekerja, baik karena sudah mencapai usia pensiun yang telah ditetapkan atau karena adanya kesepakatan antara individu yang bersangkutan dengan perusahaan tepat indivdiu bekerja untuk melakukan pensiun dini. Havighurst (dalam Azizah, 2011) menyebutkan salah satu tugas perkembangan lansia adalah menyesuaikan diri terhadap masa pensiun dan penurunan pendapatan. Setelah para usia lanjut tersebut pensiun, mereka akan merasa kehilangan peran, identitas serta status yang kesemuanya itu berpengaruh pada harga diri dan pada akhirnya akan mempengaruhi konsep dirinya juga.

Tujuan ideal dari pensiun adalah agar seseorang dapat menikmati hari tuanya dengan bahagia, namun pada kenyataannya tidaklah demikian. Perubahan keadaan dari bekerja menjadi tidak bekerja ini oleh sebagian individu dianggap sebagai keadaan yang tidak menyenangkan. Pensiun dianggap sebagai akhir dari segalanya, bagi individu yang tidak bisa menerima keadaanya tersebut.

efek psikologis pada masa transisi ke pensiun di antaranya adalah masalah identitas yang disebabkan oleh hilangnya pekerjaan, berkurangnya rasa percaya diri, kesepian, serta timbulnya perasaan cemas dan depresi (Osborne, 2012). bila seseorang pensiun maka akan mengalami kehilangan-kehilangan seperti, kehilangan finansial, kehilangan status, kehilangan teman/kelompok eksklusif dan kehilangan kegiatan/pekerjaan (Azizah, 2011). Hilangnya hal-hal tersebut dapat dirasakan sebagai sesuatu yang mengancam dan dapat menimbulkan perasaan cemas, depresi, merasa tersisihkan, pesimis, merasa tidak berguna dan berbagai macam pikiran negatif lainnya.

Semua pikiran negatif tersebut jika dibiarkan terus-menerus akan menimbulkan berbagai macam gejala baik fisik maupun psikis yang akan menyerang para pensiunan, dan jika hal tersebut dibiarkan berlarut-larut maka dapat mengarahkan pada kecenderungan post power syndrome.

Mengartikan kecenderungan sebagai kecondongan akan sesuatu (Poerwadarminta, 2007). Kecenderungan ini dapat disebut pula dengan istilah disposisi, dimana istilah pengertian disposisi adalah satu sikap emosional yang berlangsung terus-menerus (Chaplin, 2009). Post power syndrome adalah suatu syndrome yang bersumber dari berakhirnya suatu jabatan atau kekuasaan, dimana penderita tidak bisa lagi berpikir realistis, tidak bisa menerima kenyataan, bahwa sekarang sudah bukan pejabat lagi, bukan karyawan lagi, dan sudah pensiun.

Tidak sedikit pensiunan (purnawirawan) yang mengalami kesulitan dalam beradaptasi dengan masa pensiun. Mereka sulit menerima perubahan yang dialaminya di masa pensiun. Mereka yang biasanya seorang pekerja yang tekun dan optimis, kini hanya banyak berdiam diri di rumah. Biasanya yang selalu bersosialisasi dengan rekan kerja, kini hubungan tersebut terputus karena mereka tidak bekerja lagi sedangkan yang lain masih bekerja. Masih banyak lagi perubahan-perubahan yang dialami di masa pensiun. Semua ini tidak akan terjadi bila mereka telah mempunyai persiapan dalam menghadapi pensiun. Inilah satu diantara alasan perlunya mempersiapkan diri menyongsong masa pensiun.

Pensiun merupakan kesenangan atau kenikmatan bagi sebagian orang dan penderitaan bagi sebagian yang lain. Reaksi yang belakangan ini begitu ekstrem sehingga pensiun mungkin dipandang hampir seperti "hukuman mati". Walaupun mereka telah mempersiapkan diri untuk pensiun, tetapi tetap akan menghadapi masalah yang oleh Erikson disebut krisis identitas (identity crisis). 
Ada sebagian orang (terlepas dari sikap keterasingan mereka) merasa takut dan merasa menjadi orang yang tak berguna apabila masa pensiun tersebut benar-benar terjadi. Pada saat seseorang pensiun dari pekerjaannya, dia mulai melepaskan dirinya dari masyarakat. Pemikiran itu mulai terbentuk dasar dari teori "pelepasan diri secara sosial" atau yang lebih dikenal dengan "teori disengagement". Setiap pensiunan akan melewati proses ini, dan harus mampu beradaptasi diri terhadap keadaan sekeliling yang berubah, dengan cara apapun.

Para pensiunan yang biasanya energik dan kini menganggur, mereka lebih suka mencari pekerjaan atau kesibukan apa saja, sekalipun kualitas pekerjaan dan gajinya tidak sebesar dahulu. Bekerja membuat seseorang mempunyai arti dan tujuan, karena itu bekerja menjadi kegiatan sosial yang memberikan respek atau kehormatan, status sosial dan prestise sosial, yang mengikat individu dengan pribadi lain di tengah masyarakat. Kegiatan tadi khususnya digunakan sebagai kompensasi bagi emosi-emosi kekosongan, dan untuk mendapatkan kelanjutan dari pengakuan status sosialnya. Sikap yang tidak senang terhadap masa pensiun mempengaruhi kesehatan seseorang, seperti yang diutarakan Horowitz bahwa: goncangan karena pensiun adalah penyakit baru bagi orang usia lanjut.

Melihat fenomena yang ada, inilah yang menjadi alasan ketertarikan penulis untuk mengkaji lebih dalam lagi dalam sebuah penelitian ilmiah yang tertuang dalam bentuk jurnal dengan judul kondisi psikis dalam menghadapi pensiun.

\section{Metode Penelitian}

a. Rancangan Penelitian

Adapun dalam penelitian ini, penulis menggunakan metode penelitian deskriptif kualitatif dengan pendekatan induktif. Menurut Sugiyono bahwa metode penelitian kualitatif adalah metode penelitian yang berlandaskan pada filsafat postpositivisme, digunakan untuk meneliti pada kondisi objek alamiah (sebagai lawannya adalah eksperimen) dimana peneliti adalah sebagai instrument kunci, teknik pengumpulan data dilakukan secara triangulasi (gabungan), analisis data bersifat induktif/kualitatif, dan hasil penelitian lebih menekankan makna generalisasi. Menurut Sugiyono metode penelitian deskriptif adalah metode penelitian yang dilakukan untuk mengetahui nilai variabel mandiri atau lebih (independen) tanpa membuat perbandingan atau menggabungkan antara variabel satu dengan yang lain.

Metode deskriptif dapat disimpulkan sebagai sebuah metode yang bertujuan untuk melukiskan atau menggambarkan keadaan di lapangan secara sistematis dengan fakta-fakta dengan interpretasi yang tepat dan data yang selanjutnya berhubungan, serta mencari kebenaran mutlak tetapi pada hakekatnya mencari pemahaman observasi.

Adapun dalam penelitian ini penulis menggunakan pendekatan induktif. Menurut pandangan Erliana Hasan "pendekatan induktif dimulai dari fakta di lapangan, dianalisis, dibuat pertanyaan kemudian dihubungkan dengan teori, dalil, hukum, yang sesuai kemudian pernyataan hingga kesimpulan. Hal ini menggambarkan bahwa pendekatan induktif merupakan pendekatan yang berangkat dari fakta yang terjadi di lapangan selanjutnya peneliti menganalisis fakta yang ditemukan, membuat pertanyaan dan dikaitkan dengan teori, dalil, hukum yang sesuai dan ditarik kesimpulan.

Penelitian ini menggunakan paradigma interpretif dengan pendekatan yang bersifat kualitatif. Subjek penelitian adalah pensiunan TNI-AD Makorem 031/Wirabima Pekanbaru. Sementara Objek penelitian adalah kondisi Psikis Pensiunan TNI-AD dalam menghadapi pensiun. Penelitian kualitatif yaitu sebuah pendekatan yang dirasa relevan untuk meneliti fenomena yang terjadi di masyarakat, yang menempatkan pandangan peneliti terhadap sesuatu yang diteliti secara subyektif dan selalu berusaha memahami pemaknaan individu (Moleong, 2001:3).

\section{b. Teknik Pengumpulan Data}

Adapun teknik pengumpulan data dalam penelitian ini adalah melalui observasi partisipasi dan selebihnya melalui wawancara, dan dokumentasi. Observasi partisipasi yang dimaksud adalah pengumpulan data melalui observasi terhadap objek pengamatan dengan langsung hidup bersama, merasakan serta berada dalam aktivitas kehidupan objek pengamatan (Bungin, 2007). Wawancara dilakukan untuk memperoleh keterangan lebih rinci selanjutnya dengan cara tanya jawab sambil bertatap muka antara pewawancara dengan informan atau orang yang diwawancarai dengan atau tanpa pedoman wawancara, dimana pewawancara dan informan terlibat dalam kehidupan sosial yang relatif lama (Bungin, 2007). Selain itu, melalui metode dokumenter, informasi disimpan atau didokumentasikan sebagai bahan.

c. Validitas Data 
Data yang sudah terkumpul merupakan modal awal yang sangat berharga dalam sebuah penelitian, dari data yang terkumpul akan dilakukan analisis yang selanjutnya dipakai sebagai bahan masukan untuk penarikan kesimpulan. Melihat begitu besarnya posisi data, maka keabsahan data yang terkumpul menjadi sangat vital. Data yang salah akan menghasilkan penarikan kesimpulan yang salah pula demikian pula sebaliknya, data yang sah akan menghasilkan kesimpulan hasil penelitian yang benar. Keabsahan data itu dikenal sebagai validitas data.

d. Teknik Analisis Data

Proses pengolahan data dimulai dengan mengelompokkan data yang telah diperoleh dari penelitian di lapangan, yaitu dari hasil observasi yang sudah dituliskan dalam bentuk catatan lapangan, hasil wawancara, serta dokumentasi berupa buku, gambar, foto, dan sebagainya untuk diklasifikasikan dan dianalisis dengan menelaah seluruh data yang tersedia dari berbagai sumber. Proses analisis data ditempuh yaitu melalui proses reduksi data, sajian data, penarikan kesimpulan dan verifikasi. Mereduksi data diartikan sebagai proses pemilihan, pemusatan perhatian, pengabsahan dan transformasi data kasar yang muncul dari catatan-catatan yang muncul di lapangan. Data-data tersebut dipisahkan sesuai dengan permasalahan yang dimunculkan, kemudian dideskripsikan, diasumsi, serta disajikan dalam bentuk rupa sehingga kesimpulan finalnya dapat ditarik dan diverifikasikan (Moleong, 2006).

Berdasarkan pendapat diatas, maka dapat disederhanakan dalam pengertian bahwa sejumlah data yang terkumpul melalui teknik observasi, teknik wawancara dan dokumentasi digabung menjadi satu kemudian dicoba untuk dibakukan dan diolah serta dipilah-pilah menurut jenis atau golongan pokok bahasannya. Karena data yang diperoleh masih dalam bentuk uraian panjang, maka perlu sekali untuk direduksi. Penyajian data dimaksudkan sebagai langkah pengumpulan informasi yang tersusun dan memberikan kemungkinan adanya penarikan kesimpulan dan pengambilan tindakan. Selain mereduksi dan menyajikan data, tindakan selanjutnya adalah verifikasi dan menarik kesimpulan. Verifikasi dilakukan untuk memeriksa dan mencocokkan kebenaran data yang diperoleh dari hasil observasi, wawancara dan dokumentasi lalu disimpulkan. Simpulan tersebut tidak mutlak tetapi sifatnya lentur, dalam arti ada kemungkinan berubah setelah diperoleh data yang baru.

\section{Hasil dan Pembahasan}

Analisa data ini adalah untuk mengetahui bagaimana kondisi psikis personil TNI-AD Makorem 031/Wirabima Pekanbaru. Data ini dijaring melalui wawancara dan pengamatan secara langsung ke lokasi penelitian.

Kondisi Psikis Personil TNI-AD Makorem 031/Wirabima Pekanbaru Menghadapi Pensiun Kondisi yang sehat ditandai oleh bebeasnya seseorang dari gejala gangguan kejiwaan (Neurosis, gangguan kepribadfian yang ditandai dengan hadirnya keluhan) atau penyakit kejiwaan tertentu (Psikosis). Untuk menandai seseorang sehat tidaknya kondisi jiwa seseorang dapat dilakukan dengan mengetahui perasaan dan juga pemikiran seseorang terhadap sesuatu.

Dari hasil wawancara dan pengamatan diketahui bahwa perasaan personil TNI-AD Makorem 031/Wirabima Pekanbaru sukarela dengan datanganya masa pensiun. Ini dapat ditandai dengan tanggapan sebagian besar informan yang menyatakan pensiun sebagai suatu proses yang memang akan dilewati bagi setiap orang yang bekerja, karena sudah ditentukan dalam aturan atau undang-undang yang telah menetapkan adanya masa pensiun bagi yang telah memenuhi kriterianya.

Pada umumnya personil TNI-AD Makorem 031/ Wirabima menganggap pensiun sebagai sesuatu yang alami, yang harus diterima. Ini juga membuktikan bahwa personil TNI-AD Makorem 031/Wirabima menganggap baik dengan adanya masa pensiun. Walaupun ada diantara personil TNI-AD yang merasakan pensiun sebagai suatu beban baru yang mesti diterima, namun itu hanya sebagaian kecil dari personil.

Masa pensiun dianggap sebagai waktu yang tepat untuk (akhirnya) melakukan semua hal yang selalu didambakan tapi tak pernah punya waktu untuk merealisasikannya. Banyak yang memiliki mimpi-mimpi besar, mulai dari memilih tinggal di daerah pedesaan cantik yang jauh dari hiruk-pikuk ibu kota, buka usaha sendiri, hingga keliling dunia dengan uang pensiun.

Sebenarnya, keputusan pensiun lebih banyak dipengaruhi oleh faktor psikologis daripada finansial. Penekanan pada perencanaan keuangan lebih disebabkan oleh kenyataan bahwa banyak presentasi masa pensiun disediakan oleh lembaga keuangan, sementara finansial hanyalah salah satu elemen penting. Anda mungkin akan terkejut saat mengetahui bahwa banyak dari orang-orang golongan pensiun diliputi oleh keraguan bahwa mereka tidak benar-benar siap secara mental dan emosional untuk meninggalkan dunia profesional. 
Dampak psikologis negatif pada kesehatan mental yang terkait dengan transisi (misalnya, identitas diri) bisa menjadi akhir yang lebih diharapkan, mengingat konsistensinya dengan puluhan bukti ilmiah tentang dampak dari kehilangan stabilitas pekerjaan di kalangan profesional paruh baya, bahkan dewasa muda. Transisi ke masa pensiun tentu saja merupakan batu loncatan krisis perubahan gaya hidup, mengingat peran utama dari pekerjaan dan karir yang memiliki andil sangat besar dalam kehidupan kebanyakan orang.

Sejumlah studi membandingkan kesehatan mental golongan pensiunan dengan profesional paruh baya yang masih menunjukkan bahwa pensiunan (terutama laki-laki) cenderung memiliki tingkat keparahan depresi dan kecemasan yang lebih besar dari rekan-rekan kerja mereka. Pensiunan bisa kewalahan dengan begitu banyak penyesuaian dan pilihan asing yang harus dibuat ketika mereka mulai pensiun. Tergantung pada seberapa tangguhnya kepribadian seseorang, dan fakta bahwa penuaan dapat menjadi pengaruh signifikan terhadap kepercayaan diri, beberapa pensiunan mungkin tidak lagi mempercayai kemampuan mereka untuk membuat keputusan yang tepat karena ada begitu banyak yang dipertaruhkan. Lainnya mungkin merasa mereka tidak lagi memiliki energi yang diperlukan untuk menindaklanjuti keputusannya segera dan terjerumus ke dalam penundaan dan kelumpuhan keputusan. Bagi banyak pensiunan, transisi ke masa pensiun juga termasuk menjadi orang tua. Ada keyakinan luas bahwa golongan usia lanjut tidak diharapkan untuk kembali bekerja. "Pekerjaan" mereka adalah untuk menikmati pensiun dan tidak bekerja. Jika seorang pensiunan terlihat cukup tua, mereka mungkin dilabeli stereotip "orang tua" yang diasumsikan memiliki fisik lemah, sulit mendengar, dengan penglihatan kabur dan pemahaman lambat. Bahkan ketika stereotip ini menjadi dasar untuk uluran tangan berniat murni, tetap saja dapat melukai perasaan seseorang. Obyek dari stereotip ini bisa merasa bahwa mereka sengaja didorong ke arah usia lanjut lebih cepat.

Alasan untuk pensiun, apapun itu, dan usia di mana mereka meninggalkan pekerjaan, semuanya telah terbukti mampu mempengaruhi kesehatan mental di kalangan pensiunan. Di sisi lain, banyak pakar yang menduga bahwa kesehatan mental yang buruk yang diamati di antara banyak golongan pensiunan mungkin telah muncul lebih dulu daripada keputusan pensiunnya, yang justru semakin mendorong mereka angkat kaki dari dunia profesional.

Sangat perlu ditekankan disini bahwa Tidak semua pensiunan akan pukul rata mengalami perubahan hidup besar-besaran dengan cara yang sama. Diantara mereka tentunya ada yang siap dengan segala persiapannya menjelang tiba pensiun, namun ada juga yang tidak siap bahkan tidak mengharapkan datangnya masa pensiun. Ada diantara pensiunan yang dapat mengisi aktivitas pensiun dengan segala kegiatan yang bermanfaat bagi pribadinya maupun bagi orang banyak, namun masih ada juga yang merasakan keraguan untuk mengisi masa pensiun dengan kegiatan apapun.

Ada beberapa karakter yang dapat diamati dari otrang-orang yang memasuki masa pensiun, diantaranya:

1. Identitas diri Anda sebenarnya

Satu diantara beberapa kebutuhan orang untuk bekerja adalah untuk kebutuhan identitas dirinya, baik dalam keluarganya maupun masyarakat (sosial). Kadang, jabatan atau jenis pekerjaan lebih melekat pada identitas seseorang. Pekerjaan mereka adalah bagian dari diri mereka. Saat meninggalkan dunia pekerjaan, tentunya juga menyerahkan satu aspek identitas diri orang tersebut. Misalnya, orang yang biasanya memperkenalkan diri dengan "Saya jenderak di kesatuan.....," setelah pensiun tentunya akan perlu meramu sebuah identitas baru: "Saya adalah..."

Beberapa orang mungkin biasa, senang atau bahkan bangga dengan mengatakan "Saya pensiunan." Seiring waktu, mereka mungkin mulai menikmati memiliki lebih banyak waktu bebas dan menemukan pensiun sebagai perubahan yang menyenangkan dari stres sehari-hari yang mereka alami dalam pekerjaan. Tetapi yang lain akan lebih bahagia jika mereka berusaha untuk mendefinisikan identitas diri pasca-pensiun yang akan memberikan fondasi bagi keseharian mereka dan makna bagi kehidupan mereka.

Inilah fenomena yang terjadi di personil TNI-AD Makorem 031/Wirabima Pekanbaru, sebagian peneliti temukan di antara personil yang menikmati masa pensiun dan senang dengan menyebutkan dirinya sebagai pensiunan TNI-AD serta tidak enggan berbagi pengalamannya selama dinas aktif. Namun tidak dipungkiri masih ada ditemukan beberapa pensiunan TNI-AD yang merasakan adanya penurunan identitas diri dengan enggan untuk menyatakan identitas dirinya sebagai pensiunan.

2. Hubungan Anda dengan orang lain

Di kala aktif bekerja, tentunya banyak orang dan rekan kerja yang ditemui. Ini menjadi suatu kebutuhan sebagai makhluk sosial yang saling berinteraksi. Ketika pensiunan meninggalkan kehidupan kerjanya, diantara mereka sering kehilangan hubungan dengan orang-orang yang pernah menjadi bagian dari rutinitas mereka, sehingga mereka perlu mengembangkan hubungan baru. Mulai 
membuat kenalan di luar pekerjaan dan terlibat dalam kegiatan yang mereka inginkan setelah pensiun. Ada mungkin yang melakukannya dengan travelling, terlibat dalam kegiatan sukarela, atau juga aktif dalam organisasi, dan lain sebagainya.

Lain kenyataan yang ditemui, ada juga hubungan mereka (pensiunan) dengan pasangan atau keluarganya juga dapat berubah, karena mereka tentunya akan menghabiskan lebih banyak waktu bersama dengan keluarga. Kadang, terlalu banyak kebersamaan menyebabkan orang untuk lebih cepat bosan dan/atau tersinggung untuk hal-hal kecil satu sama lain. Jika kedua suami dan istri pensiun di saat yang sama, misalnya, masalah mungkin timbul dari siapa yang akan memegang channel TV duluan. Atau pensiunan dan anak-anak dewasa mereka mungkin memiliki prinsip yang berbeda antara mereka dengan keluarga, anak dan cucunya.

3. Tujuan dan semangat hidup

Hal ini terkait dengan identitas orang yang memasuki masa pensiun. Tujuan hiduplah yang membuat semangat mengisi hari-hari di masa pensiun. Semangat menemukan tujuan hidup baru dapat memberikan rasa optimisme menghadapi masa pensiun.

Memandang pensiun sebagai kesempatan untuk memulai bab baru dalam hidup, mungkin berarti melanjutkan apa yang telah mereka lakukan pada skala yang berbeda dari rutinitas yang biasa mereka lalukan. Mengambil kegiatan lain atau yang bisa menggunakan keterampilan yang dimiliki bisa menjadi alternatif bagi pensiun dalam mengisi waktu luang selama masa pensiun.

\section{Kesimpulan}

Perencanaan masa pensiun dapat menjadi pengalaman menakutkan, penuh frustasi bagi banyak orang, yang mengapa beberapa orang memilih untuk menundanya. Namun dengan penundaan akan datang hilangnya kesempatan bagi pemahaman yang lebih baik, untuk memanfaatkan dana pensiun seoptimal mungkin, dan untuk menghindari masalah di masa pensiun.

Personil TNI-AD Makorem 031/Wirabima Pekanbaru sebagian besar siap menghadapi pensiun dengan sukarela, menganggap masa pensiun sebagai sesuatu yang alami, yang mesti diterima dengan berjiwa besar. Walaupun tidak dipungkiri adanya sebagian personil yang mengalami kondisi yang berbeda dengan yang diharapkan, seperti adanya ketidaksiapan adanya perubahan identitas diri, hubungan dengan orang lain yang kurang harmonis baik dalam keluarga maupun dengan masyarakat, dan semangat dan tujuan hidup yang perlu diperbaiki.

Personil TNI-AD Makorem 031/Wirabima Pekanbaru sudah mempersiapkan diri jauh sebelumnya dalam menghadapi pensiun. Selain mempersiapkan dalam bidang materiil dan fisik, juga penting mempersiapkan mental dalam menerima segala perubahan yang akan terjadi di masa pensiun. Personil TNIAD siap menghadapi pensiun didukung oleh pembinaan mental (Bintal) yang difasilitasi Makorem, persiapan materiil dari personil sendiri dan keyakinan agama yang dimiliki sebagai penuntun dalam kehidupan.

\section{References}

Bambang, W 1987. Kebahagiaan Perkawinan Dalam Masa Pensiun (Skripsi). Jakarta : Fakultas Psikologi Universitas Indonesia.

Bjorklund, B. R., dan Bee, H. (2009). The journey of adulthood. Pearson Education International

Bungin, Burhan. 2007. Penelitian Kualitatif. Jakarta: Kencana Prenada Media Group Bungin, M. Burhan. 2008. Penelitian Kualitatif. Jakarta: Kencana Prenada Media.

Bungin, Burhan. Sosiologi Komunikasi: Teori, Paradigma, dan Diskursus Teknologi Komunikasi di Masyarakat. Jakarta: Kencana, 2007.

Faisal, Sanapiah. "Penelitian Kualitatif; Dasar-dasar dan Aplikasi". Malang: Yayasan Asih, asah dan asuh. 1990.

Eliana, R. (2003). Konsep diri pensiunan. Program studi Psikologi Fakultas kedokteran Universitas Sumatra Utara. Di akses pada 19 Oktober 2012, dari: http://repository.usu.ac.id/ bitstream/ 123456789/ 3632/1/psikologi-rika\%20 eliana.pdf.

Handayani, Y. (2008). Post power syndrome pada pegawai negeri sipil yang mengalami masa pensiun. Depok. Universitas Gunadarma. Di Akses pada tanggal 21 Maret 2013 dari :

http://www.gunadarma.ac.id/library/articles/graduate/psychology/2008/Artikel 10503211.pdf

Moloeng, Lexy. "Metodologi Penelitian Kualitatif". Bandung: Remaja Rosdakarya. 1989.

Mudjiyanto, Bambang."Metode Penelitian Komunikasi Berbasis Internet." Jurnal Studi Komunikasi dan Media, 2016

Poerwadarminta, W. J. S. (2007). Kamus umum Bahasa Indonesia (Edisi 3). Jakarta: Balai Pustaka. 
Pradono, S. G., dan Purnamasari, E. S. (2010). Hubungan antara penyesuaian diri dengan kecemasan dalam menghadapi masa pensiun pada pegawai negeri sipil di Propinsi Daerah Istimewa Yogyakarta. Fakultas Psikologi Universitas Mercu Buana Yogyakarta. Di Akses pada tanggal 19 Oktober 2012 dari :http://fpsi.mercubuana-yogya.ac.id/wpcontent/uploads/2012/06/Agustus_2010_Santi-Esterlita-P.pdf.

Purwanti, P. (2009). Post power syndrome pada purnawirawan Kepolisian Negara Republik Indonesia ditinjau dari konsep diri. Skripsi (tidak diterbitkan). Semarang. 